\title{
The Extent of Problems and Prospects of Enabling Multimedia Classroom in a City Girls' College in Bangladesh
}

\author{
Deb Proshad Halder \\ Department of English, Faculty of Arts \& Humanities, Jashore Government Girls’ College, Jashore, Bangladesh
}

Email address:

debproshadhalder@gmail.com

\section{To cite this article:}

Deb Proshad Halder. The Extent of Problems and Prospects of Enabling Multimedia Classroom in a City Girls' College in Bangladesh. International Journal of Secondary Education. Vol. 7, No. 3, 2019, pp. 61-68. doi: 10.11648/j.ijsedu.20190703.11

Received: June 17, 2019; Accepted: July 22, 2019; Published: August 5, 2019

\begin{abstract}
The aims and objectives of this paper is to justify the urgency and the strength of enabling multimedia classroom. the term 'urgency' is deliberately inserted because the paper will try to present how much reliance a student of a city, even a district level big towns, has built up on the online resources, promotional as well as entertaining and educational videos to procure in - text and out -of- text lessons. The dependence of the students on digital/visual format of resources can be epitomized as strength (both from the part of the learners and instructors) of using multimedia in a classroom. The new generation learners are being adapted and adopted with the idea of obtaining, transferring and disseminating information through digital contents via various social media. The educational institutions are now laboring much to materializing the trend of digitized generations to keep them connected with the institutions, teachers and texts. But this paper studies that problem prevails. Enabling multimedia classroom is not an economical process as a lecture method for imparting lessons. It requires several electronic and digital tools as well as the suitable classroom environment to establish those tools, the administrative decision and the academic efficiency. Several internal as well as external factors impede administrative as well as academic proficiency and efficiency which are hindering implementation of multimedia classroom in a girls' college situated in a city of Bangladesh. This paper aims to curve out the problems in this attributive institutions of Bangladesh. The purpose of this initiative through explorative study is to identify the basic problems, which impede the creation of digitized classroom, and recommend probable ways for solution as the students' orientation with digital version of learning should extend the plausibility of creating learner friendly multimedia classroom.
\end{abstract}

Keywords: Multimedia, Prospects, Challenges, Administrative, Academic, Girls, Bangladesh

\section{Introduction}

The pertaining and perceiving of instruction for the purpose of education has been undergoing rapid transformation at the scale of the assortment and use of varied teaching aids and tools as Begum [1] has opined that ' cell phone has great potential as an instructional tool'. The lecture method is losing its sole priority as the way of instruction in the classrooms as the learners are extending their reliance on the online tutors and various socio educational media as Prensky states that cell phone can be effectively used for learning and 'cell phones with wireless internet access offer a world of possibilities for classroom instruction' [2]. The ideation of the assortment of various tools, those are for the purpose of enabling a suitable environment for multimedia classroom, is now incorporated with one of the proved teaching methods even in Bangladesh as the recent report of an online newspaper [3] claims the mobile phone users in Bangladesh tops 140 million while the population of Bangladesh claims to have been 164.7 million [4] that aligns with very general notion of having a cell phone of per person which fosters the idea of a student's orientation with technology at hand, that raises the possibility of introducing multimedia class from the part of the instructors as Langu \& Lekule contends that the effectiveness of a class relies on the willing participation of the students and learner - centered approach is developed with the thought that a learner will have engagement in class through addressing their interest, that originates from their prior 
knowledge and experience which tend to please them [5]. This paper tends to explore the socio - cultural experiences the learners are amassing in their bucket of mind (here the experience of the technological affixation for them to acquire information for the purpose of institutional as well as non institutional education). A student, having interaction with technology aided learning out of the class, seems to have acquired the taste of multimedia enabled learning apart from the teachers in the classes and here lies the opportunity from the teachers to address the attention of the learners through introducing technology oriented learning method along with traditional lecture methods. The learners, representing their community, bring community knowledge in the classroom and multimedia classroom with the assistance of technological devices as teaching aids becomes priority for that community learners if the teaching implies the philosophy of learner - centered approach in teaching learning process [6]. The learners, with their credibility of technology orientation, epitomize the opportunity for the institution to be imparted class lessons through the use of multimedia. The doubt may arise whether the priority of learner's experience for disseminating class lectures through multimedia really works.

The directives stated in the Reference [7] provides the idea, that suffices to elapse the doubt regarding the credibility of introducing multimedia class for successful class management, which contends that using multimedia in teaching provides much scope to the learners to "organize, synthesize and develop" an eye - catching experience of visible contents that they learnt audibly.

The learners, the targeted group, whom the institution tends to provide lessons with the modern method of class practice through introducing digital contents are indicated as prospects in the title due to the habituation of the learners. But the paper indicates a few major factors as challenges, threats or weakness, if it is termed as SWOT analysis (SWOT implies Strength, Weakness, Opportunity and Threat) to enable a multimedia class and to create learner friendly classroom environment. Some interlaying factors emerge when an institution inclines to afford a multimedia oriented class. An instructor must have expertise on technology, pedagogy and content knowledge to impart an effective multimedia based class lecture [8]. Again, the financial sufficiency / insufficiency of this institution must not be kept untouched to identify the prospects and challenges of enabling multimedia classroom as the title presents the research area as a city girls' college in Bangladesh that is reported by the respondents (which will be presented in the findings area) struggling for resources. The institution, as it cannot overlook the possibilities and prospects of using multimedia in classes for the purpose of lecture, must address the emerging problems and challenges in order to evaluate the experience of the learners for letting them fully concentrate in class lectures and this paper tries to dig out whether there lies wider gap between the expectations of the learners and the efficiency of the instructors as well as the institution and if it remains true it tends to find the probable way out to redress the gap.

\section{Literature Review}

The Reference [9] excerpts that the rate of technology use in the students reach to that position they are likely to regard as the 'global citizens' which creating a vacuum between the teachers in the class and their targeted groups, students. This reference [9] adds a comment from Beyrouti, the Middle East Manager of Arab Business Machine, which is the authorized distributor of Apple who designates how technology poses threat to the core value of a teacher to the students owing to technology dividend prevailing in the teachers and students.

"Consider technology as a language. Teachers are left with the task of teaching students a language they've already mastered. If they're not losing jobs to technology, they are definitely losing respect.

That is where the resistance comes from."

The subject matter is that the use of multimedia in a class is likely to be appraised by the students, but the problems lie on the instructors.

But many things need to be solved before finalizing the idea of using multimedia in a class that is; (a) whether all types of learners (auditory learners, visual learners etc.) are benefited equally, (b) whether class size matters and (c) whether gender issue affects the results because the paper studies a girls' college of a city in Bangladesh.

The recent brain research on the mode of learners' perception of lessons in classroom practice emphasizes that human brain takes in information visually more likely than any other senses [10] and the graphic presentation of lessons expedites frequency and rate of learning [11].

The study area of this paper claims that class size needs to be investigated because this institution lets the students get admitted in three sections (science, arts and commerce section) with 100 students in each section and this inclusion makes almost 600 students at the first year and second year in the college as the Higher Secondary level education ranges two years of term. Thus, every section includes one hundred students. Addonizio \& Phelps [12] has deleterious observation on the class size and student performance stating the findings on fall of class size increasing the rate of achievement of the students. Asadulla [13] adds alternative observation unlike Addonizio \& Phelps as Asadulla has argued with evidence that class size impacts mostly in the elementary levels where as the learners who belong to secondary and higher levels are privileged with little instructor intervention, interactive learning atmosphere among fellow learners and a learner's willingly participation in class responses. It urges that class size is unexpectedly large (as the targeted institution of this paper refers to a state of one hundred students in a section being total three hundred students in the sections of science, arts and commerce in the first or second year consecutively) in cities of Bangladesh not excluding girls' college but the achievement rate to the expected level is satisfactory meaning the class size not impeding the achievement of the learners in the targeted 
(secondary and higher secondary levels) levels.

Buckingham [14] has remarked on the issue of the quality of teacher that lets the students raise themselves to the rate of achievement. Class size matters little if the teachers are competent enough with the endowment of required quality. The focus in on ensuring the quality of the teachers and the reference [15] designates several factors in order to address the up gradation of the lecture delivery system to meet the needs of technology enabled generation. Eltahir [15] identifies that a teacher (a) must create digital content by his own hands, (b) use of specified hardware, software and curriculum must be justified by them who are unswervingly predetermined to engage the learners in the class with effective lecture dissemination. $\mathrm{Xu}$ [16] addressed the aforementioned competent and quality of a teacher as higher level of skills on computer and technicality. It is that challenges an institution, that tends to generate multimedia inclusive classroom, teachers often lack and (d) the multimedia presentation collapses due to electricity outage, software misbehavior etc.

Again, educational institutions require additional resources in order to accord some tools such as, 'networked computers, storage devices, printers, scanners, LCD projectors, electronic whiteboards, digital camera and camcorders [17] to enable a multimedia class. Here the observation of Eltahir [15] tends to be applicable, even in the context of the study area to be indicated in the paper, that 'We face financial constraints that will not quickly disappear.

The perspective of global educational dynamism and the technology generated learning connectivity on the part of the learners justify the credibility of multimedia enabled classroom and the thought of resource constraints and teachers' competence quest lead the viability of enabling multimedia classroom to a researchable specter.

\section{Methodology}

The study area has been dignified as a 'City Girls' College' where a city designates as a divisional or district area where the educational institutions bear the probability of inclusive participants representing poor class, middle class to higher class of family background students due to the online system of admission based on secondary level results and these colleges are first graded chosen owing to their annual performances. The selection of Girls' College is purposive as a recent study by Daffodil International University published in an online newspaper of Bangladesh [18] enflames the quest whether girls are characterized as challenge to the process of multimedia integrated learning and teaching. Mixed method approach (quantitative data is analyzed to explore the extent of qualitative values of problems and prospects of the enabling multimedia classroom in a girls' college in cities) has been applied to discern the quest of the paper indicative through the title.

\subsection{Identification of the Study Area}

Jashore Government Girls' College has been selected as study area and the college situated in the hub of city accords 25 classrooms with only three multimedia classrooms except a computer lab with thirty three computers for the use of students [19]. The Table 1 shows the physical conditions of this study area:

Table 1. The Physical Dimension of the Research Area.

\begin{tabular}{ll}
\hline Area & 2.89 acres \\
Building & 5 buildings \\
Classroom & 25 classrooms \\
Computer Lab & 1 (33 microcomputers) \\
Multimedia classroom & 3 classrooms \\
Internet connectivity & 1 room (computer lab) \\
\hline
\end{tabular}

The reference [20] fosters the statistics of the learners and teachers in this institution. It covers approximately 5,974 students (including higher secondary, Honors and Masters level) where the Higher Secondary level students number only 652 students (the focus area of this paper is the students of Higher Secondary Level). They are provided with three larger classrooms for three sections and only one multimedia enabled classroom.

Table 2. The Population Update of the Study Area.

\begin{tabular}{ll}
\hline Sections & Number of students \\
\hline Science & 210 \\
Arts & 295 \\
Commerce & 147 \\
Total & 652 \\
\hline
\end{tabular}

\subsection{Stratification of the Population}

The researcher selected one hundred respondents from the present students randomly to serve the questionnaire for their response. The respondents were at the ratio of 33:34:33 (science: arts: commerce) chosen randomly and they were invited to sit in a large room for the purpose of the survey.

\section{Sampling of the Student population}

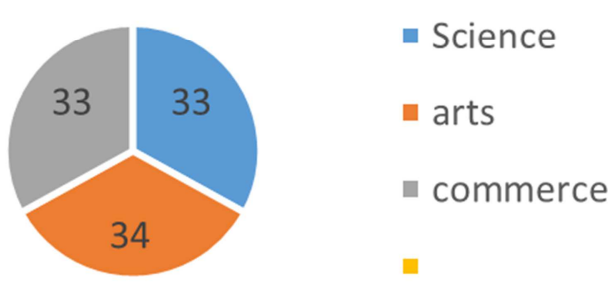

Figure 1. Stratification of the Sample.

Regarding the selection of the teacher as strata the convenience sampling technique was applied to choose twelve respondents among the 67 staffs of teachers purposively. The major three sections in this college includes nine departments and every head of the department along with three ICT (Information and Communication Technology) teachers were invited for survey [20]. 
Table 3. Sampling of the teacher population.

\begin{tabular}{ll}
\hline Department & Head \\
\hline English & 1 \\
Bangla & 1 \\
History & 1 \\
Islamic History and Culture & 1 \\
Economics & 1 \\
Political Science & 1 \\
Geography & 1 \\
Botany & 1 \\
Zoology & 1 \\
ICT (Compulsory Subject) & 3 (Teachers from various department) \\
Total & 12 \\
\hline
\end{tabular}

\subsection{The Research Instruments}

Two structured questionnaires have been used for the purpose of the survey. This paper tends to explore the strength and the weakness of the institution to enable multimedia specially focusing on the measurement of the capability of the girls' to be introduced with the modern delivery system of lectures. The Appendices 7.1 and 7.2 show the structured questionnaire

\subsection{Data Collection Procedures}

This research tends to measure the digital technology connectivity of the students in this study area, for the paper is likely to weigh whether multimedia enabling classroom is essential, whether the learners are capable enough to adapt with the new method of learning, whether the instructors as well as the institution are efficient to provide with this new methodological class lectures. To ask for the solution of above mentioned quarries, the 100 printed copies of questionnaire were served to the sampled respondents and the response sheets were then collected from them after fifteen minutes. Before serving the questions rapport was developed among the respondents with the provision of a candy to every participant. The participants were explained how they will respond and they were encouraged to respond frankly as their names were not asked for. The teacher respondents were very much enthusiastic and they were given time to think for the responses. Thus, the data were collected on basis of the questionnaire.

\subsection{Techniques of Data Analysis}

The Appendix 7.1 congregates seven questions including four stimuli. The following chart arranges the frequency of the stimulus retrieved from the responses of one hundred student participants. It is only a numerical ordering to measure the frequency of the arrival of the stimuli. This has been done through content analysis.

Table 4. The Numerical Response Chart of the Student Respondents.

\begin{tabular}{lllll}
\hline Questions & Stimulus first & Stimulus second & Stimulus third \\
\hline First & 68 & 4 & 1 & Stimulus fourth \\
Second & 25 & 11 & 3 & 61 \\
Third & 33 & 45 & 10 & 12 \\
Fourth & 72 & 26 & 0 & 2 \\
Fifth & 72 & 27 & 1 & 0 \\
Sixth & 46 & 49 & 57 & 4 \\
Seventh & 8 & 29 & 57 & 6 \\
\hline
\end{tabular}

The response frequency from the teachers has also been analyzed to figure out the quantitative values of the problems indicated in the questionnaire. The following response frequency chart is developed by analyzing the responses of the questions indicated in the Appendix 7.2.

Table 5. The Numerical Response Chart of the Teacher.

\begin{tabular}{llll}
\hline Question & First Stimulus & Second Stimulus & Third Stimulus \\
\hline First & 4 & 8 & 0 \\
Second & 3 & 3 & 6 \\
Third & 0 & 12 & 0 \\
Fourth & 0 & 12 & 0 \\
Fifth & 5 & 6 & 1 \\
\hline
\end{tabular}

\section{Major Findings}

The data found through questionnaire survey have been waged frequency measurement and organized through numeric scale. The paper tended to measure, firstly, the potency/ impotency of the target group, girls of the study area. Then, it intended to measure the competence of the teachers and the quality at the scale of technology operational capability.

\subsection{The Technology Density Among the Students and Teachers}

The first question is intended to measure the technology density among the students, here the use of mobile phone has been regarded standard to measure technology connectivity. 68 students among the one hundred participants are found to have at least a mobile phone. The Figure 2 projects below the potency / impotency of technology orientation of the students of Higher Secondary level:

\section{The USERS OF MOBILE PHONE}

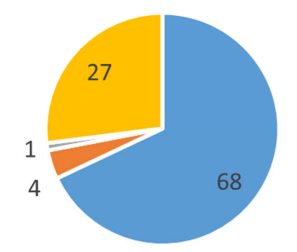

| phone:1 |

Figure 2. The Number of possession of phones by the students. 
The following figure (Figure 3) refers to the findings on the assortment and capability of having as well as dealing well with the presentation of digital content in the classroom. But the findings were frustrating as the four respondents among twelve possesses personal computer which is rated $33.33 \%$ of one of the greatest components of multimedia class operation. Here, the paper finds a wide gap between the teachers and the students as the rate of students' density of technology use $(68 \%)$ is widened.

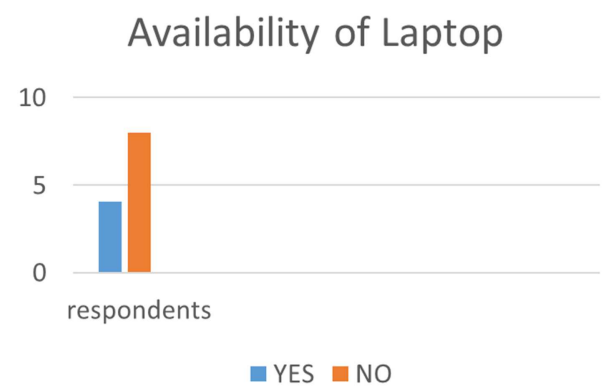

Figure 3. The Frequency of Laptop use among the Teachers.

\subsection{The Rate of Internet Connectivity}

But the frustrating scenario prevails if the internet connectivity of the students is explored $61 \%$ students are reported to have no daily basis connectivity with the internet. Other $39 \%$ respondents have internet connectivity.

\section{INTERNET BROWSING RATE/DAY:}

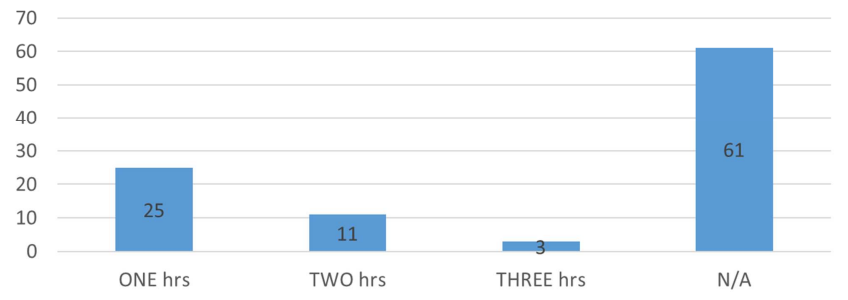

Figure 4. Internet Use Density among The Students.

Again, the Figure 5 a little bit increase of internet users to $45 \%$ though it happens only for once or twice the students have used internet for the purpose of getting any information related to exam dates, results etc.

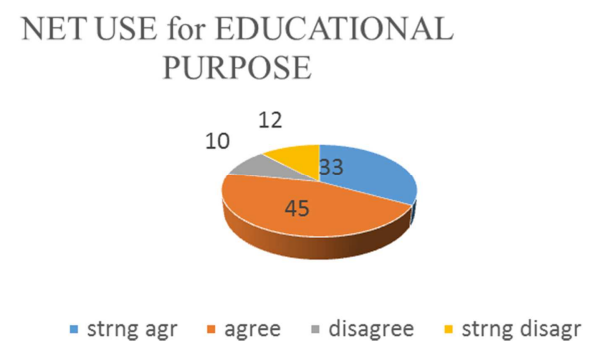

Figure 5. Internet Use Rate for Educative Purpose.

\subsection{Multimedia Orientation and Satisfaction}

The participants are, at any stage of their formal/institutional learning, imbued with the experience of multimedia class. They are reported here $72 \%$ of rate who have had that orientation and the satisfying matter is that they all are satisfied with such type of lecture delivery.

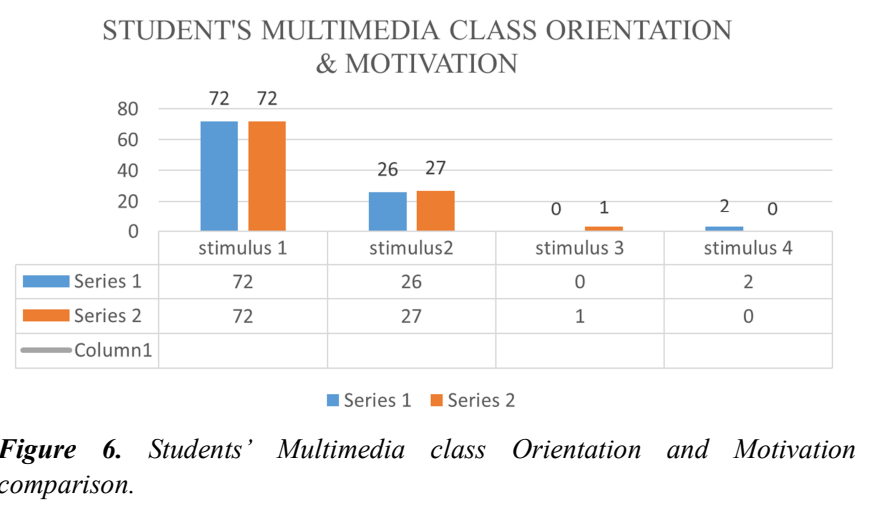

According to The question five of the Appendix 7.2, the teacher respondents show their disgust on the institutional arrangement of tools for the materialization of multimedia classroom, 8 respondents are not satisfied with the institutional provision. As it is reported that this institution accords only a computer lab with 33 computer and the teachers are not provided with a computer and this institution has three multimedia classroom for 652 students [19].

\subsection{Negligence on Participating at In-house and Pedagogy Training}

The remarkable findings that attract the attention is that the teachers are found to have no pedagogy training and even they have negligence on in-house training also.

\section{Analytical Appreciation}

The analysis or analytical appreciation, let us not call it depreciation, tends to focus on a stunning matter that the indicated college has been able to arrange only three to four multimedia classroom out of twenty five classrooms. However; the students express their satisfaction on the state of arrangement of multimedia availability in the institution. 46 respondents expressed 'Strongly Agree' with the technology arrangement while other 49 respondents were in the side of positive acceptance of the performance of this institution. But, more interestingly, 8 respondents agree on the teacher's capability of disseminating class through multimedia.

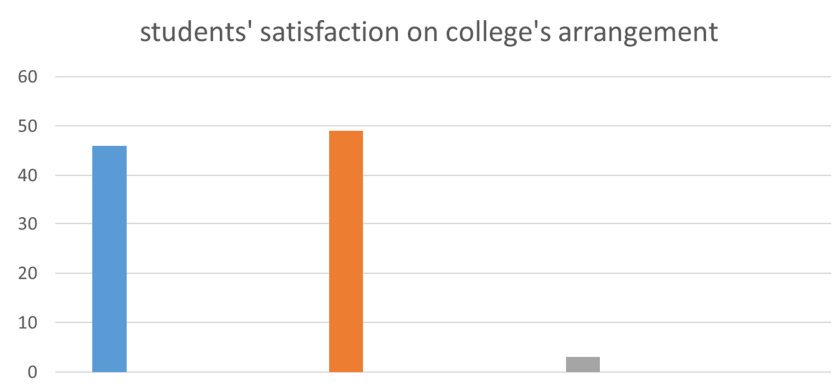

Figure 7. Institutional Providence of Multimedia class and Students' satisfaction responses. 
This anomalous findings have an apparent analysis that the learners, perhaps, are satisfied with what they are provided through computer lab (easy access to use a laptop, easy access to internet, learning of basic computing etc.). This paradigm shift of girls to come out of their stereotypical mentality of distantness from technology use is likely to approve the observation of Bari [21] that 'Revolutionary new apps, uses of information and communication technology smashes the stereotypes that holds girls back'.

\subsection{Wide Gap Between Mobile Ownership and Internet Density}

The findings show the $68 \%$ girl students own a mobile phone whereas $27 \%$ students do not possesses a personal mobile phone which may be termed as a positive shift as Bari [21] states men are more likely twice users of mobile phone comparatively to women in Bangladesh. This paper also states in para 9 that only $10 \%$ women work in ICT sectors and this research paper has been able to identify the problem of not being connected to the internet as this paper finds only $39 \%$ respondents use internet while the majority share of $61 \%$ respondents have no access to internet though they possesses a mobile phone.

\subsection{Teachers Must be Focused on}

Patel [22] has opined that an instructor mastered with technology knowledge is rare. And the findings of this paper affirms the proposition of Patel as 12 respondent participants have no in - house training (a short course training on how to make digital content taken within the institution) and they feel reluctant to have pedagogical knowhow on digital content making. This reluctance makes the digital citizens (the learners in this era) show disbelief on the teachers [9]. If teachers want to retrieve their faith they must build technological capacity to meet the demands of this modern learners endowed with technology.

\section{Conclusion and Recommendation}

The idea of enabling multimedia classroom in a girls' college is beset with multi tired probabilities. The probability is both prospective and challenging as well as daunting. The girls cannot be characterized, in the context of Bangladesh, as unsolvable challenges. Rather; this paper tends to show how technologically connected they are gradually becoming. They are building a association with technology oriented educational process. Now the great challenge is the teachers who are now on the verge of failure if they cannot enable to satisfy the demands of the today's learners. The maintenance of the large class size of students, and more necessarily the ability of instructors to combine the traditional lecture method with the new multimedia class presentation approach are the demand of this type of city colleges. But the issues and challenges are not inevitably unsolved and unaddressed. The primary priority must be bestowed on the capacity building of the institute to have the provision of necessary tools of multimedia -enabled environment, and the maintenance of utility service in the institution that implies the idea of human resource development to provide technical assistance to the teachers during creating power point, presenting it in the class and providing assistance in the time of tools management if it is required.

Proper management of multimedia is another burning factor which needs to be recommended to follow for the effective use of multimedia teaching. Only multimedia converted class cannot ensure the benefit of it to the students because the needs, the attentiveness, the interaction, and the emotive aspect of a lesson must be reflected through the effort of multimedia presented class. Otherwise, the prime target of class is not achieved. So to say, pedagogical knowledge and technological expertise needs to be incorporated in a teacher and for which training for the teachers is priority that will enable the instructors (a) correctly understand the impact of multimedia teaching.

Again, the lesson plan must focus on the interactional class practice because a teacher gets scope to predominate over the students through the manipulative nature of digital presentation. Here, a teacher must be a good time manager neither extending a digital presentation too long, nor curtailing a presentation too short. This needs to be inspected time and again with arranging bilateral (1. the college administration including teachers and 2. the students) open discussion session to dig out the challenges the students face in the multimedia -enabled class. This tends to create awareness among the teachers how to incorporate the will of teachers and learners in a multimedia -presented class.

\section{Appendix}

\section{Questionnaire for the Students}

1 How many mobile phone/s do you have?
(a) One
(b) Two
(c) Three
(d) None.

(c) Three hour
(a) One hour
(b) Two hour
ne at least once for educational purpose

3 You have used internet in phone at least
$\begin{array}{ll}\text { (a) Strongly agree } & \text { (b) Agree }\end{array}$

(c) Disagree

$4 \quad$ You have attended at least a class with the presentation of digital content?
(a) Strongly agree
(b) Agree
(c) Disagree
(d) Strongly disagree.

(d) Not applicable.

(d) Strongly disagree.

5 Multimedia class can make your lessons easy... 

(a) Strongly agree
(b) Agree
(c) Disagree
(d) Strongly disagree.

6 Your institution makes the arrangement of multimedia class.
(a) Strongly agree
(b) Agree
(c) Disagree
(d) Strongly disagree.

7 All the teachers use multimedia in classroom to present lessons.
(a) Strongly agree
(b) Agree
(c) Disagree
(d) Strongly disagree.

\section{Questionnaire for the Teachers}

1 you own a laptop to use for the purpose of class
(a) yes
(b) no
(c) other

2 Large class size necessitates multimedia.
(a) yes
(b) no
(c) other

3 Have you participated in house training on the use of multimedia?
(a) yes
(b) no
(c) other

$4 \quad$ Have you any training on pedagogy?
(a) yes
(b) no
(c) other

5 Do you think this college provides requisite facilities for multimedia class?
(a) yes
(b) no
(c) other

\section{References}

[1] Begum, Roksana. Prospect for Cell Phones as Instructional Tools in the EFL Classroom: A Case Study of Jahangirnagar University, Bangladesh. Canadian Center of Science and Education, 2011. Vol. 4, No. 1; 105-115. www.ccsenet.org/elt Retrieved from https://files.eric.ed.gov/fulltext/EJ1080334. pdf.

[2] Prensky, M. What can you learn from a cell phone? Almost anything! Innovate Journal of Online Education, 2005. 1 (5) Retrieved from http://www.innovateonline.info/index.php?view=article\&id=8 3.Pouezevara.

[3] Correspondent, S. Mobile Phone Users in Bangladesh Top 140 Million. 2017, November 14. bdnews24.com, pp. A4. Retrievedfrom

https://bdnews24.com/business/2017/11/14/mobile-phoneusers-in-bangladesh-top-140-million.

[4] The Population of Bangladesh (2017) Retrieved from https://www.google.com/search?q=the+population+of+Bangla desh\&rlz=1C1GGRV enBD851BD851\&oq=the+population+ \&aqs $=$ chrome. $1.69 \mathrm{i} 57 \mathrm{j} 015.12214 \mathrm{j} 0 \mathrm{j} 7 \&$ sourceid $=$ chrome $\& \mathrm{ie}=$ UTF-8.

[5] Langu N, Lekule T. The Effectiveness of Learner-Centred Approach in Teaching and Learning Geography in Secondary Schools: A Case of Nkoaranga and Nasholi Secondary Schools in Arumeru. Tanzania Journal of Education Vol No. 3 June, 2017; ISSN 9789987853007: Pg 126-136 www. makumira. ac. Tz.

[6] Bransford JD, Brown A L, and Cocking 1 R. How People Learn: Brain, Mind, Experience and School: Expanded Edition. The National Academies Press. Washington, DC. 2000; https://doi.org/10.17226/9853.

[7] Penuel W R, Means B, and Simkins M. Teaching the information generation. Educational Leadership. October. 2000; 58 (2): $34-38$

[8] Blumenfeld P, Soloway E, Marx RW, Krajcik JS, Guzdial M \& Palincsar A. Motivating project-based learning: sustaining

the doing, supporting the learning. Education Psychologist. $1991 ; 26,369-398$.

[9] Sankar, Anjana. Technological gap between teachers and students widen Gulf News. 19 November 2010: A4. Retrieved from https:/gulfnews.com/uae/education/technological-gapbetween-teachers-and-students-widen-1.714232.

[10] Wolfe P. Brain matter: Translating research into classroom practice. Alexandria, VA: Association for Supervision and Curriculum Development. 2001.

[11] Schunk D H. Learning Theories: An Educational perspective (6th ed. Boston, MA: Pearson 2012. Retrieved from: https://www.researchgate.net/file.

[12] Addonizio M \& Phelps J. Class Size and Student Performance: A Framework for Policy Analysis. Journal of Education Finance, 2000; 26 (2), pp. 135-156. Retrieved from https://www.jstor.org/stable/40704119.

[13] Asadulla M. Class size and student achievement in developing countries: Evidence from Bangladesh. 2019. Retrieved from https://www.researchgate.net/publication/228858655.

[14] Buckingham J. Class Size and Teacher Quality. Educational Research for Policy and Practice. 2003, Volume 2, Issue 1, pp 71-86. https://doi. org/10.1023/A:1024403823803.

[15] Eltahir, Mohd. Elmagzoub. For Effective Use of Multimedia in Education, Teachers Must Develop their Own Educational Multimedia Applications. Turkish Online Journal of Educational Technology. 2015. 4. 62-68.

[16] Xu X. Study on Effective Using of Multimedia Teaching System and Enhancing Teaching Effect. International journal of Engineering and Technology. 2017; 12 (6) Retrieved from https://doi.org/10.3991/ijet.v12i06.7093.

[17] Eskicioglu A M \& Kopec D. The Ideal Multimedia-Enabled Classroom: Perspectives from Psychology, Education and Information Science, 2003; doi:/10.1.1.94.8494.

[18] Star Online Report. Of the ICT Sector in Bangladesh, only 16\% are women: Study. Mar 6, 2019. Retrieved from https://www.dailystar.net July 20, 2019.

[19] Jashore Government Girls' College. (July 20, 2019) Retrieved from https://www.jgmc.gov.bd 
[20] Jashore Government Girls' College. (July 20, 2019) Retrieved from https://www.jgmc.gov.bd/statistics.

[21] Bari A. Bridging the Gap: Girls' Potential in Bangladesh's ICT Sector. April 28, 2018. The Daily Sun, pp A4. Retrieved from https://www.daily-sun.com.
[22] Patel C. Use of multimedia technology in teaching and learning communication skill: An analysis. International Journal of Advancements in Research \& Technology. 2013; 2 (7), 116-123. 